\title{
o novo homem
}

Este novo homem

tem um jeito estranho.

Faz bem,

a cara que não tem.

"A cara do pai"

Tomara que não.

Trabalha pesado,

barulhos produz.

Não adivinhamos

o que está querendo.

Respira, rumina,

rasteja, resmunga.

Hesitando, descobre

os dois lados da coisa.

Trepa nas palavras,

testando

gangorras, balanços,

ousadia, medo.

Um dia, mais esperto

que nós, nos espanta.

Então, enquanto aos poucos

morremos,

a sua cara vai ficando,

mais e mais, a nossa cara.

336. Poemas de Hans Magnus Enzensberger 